\title{
"I Do not Let Setbacks Discourage Me Much" The Composition of a Finnish Female Leader
}

\author{
Sanna Hyvärinen ${ }^{1}$, Satu Uusiautti ${ }^{1} \&$ Kaarina Määttä ${ }^{1}$ \\ ${ }^{1}$ Faculty of Education, University of Lapland, Rovaniemi, Finland \\ Correspondence: Sanna Hyvärinen, Kuusirinteentie 3b8, 96100 Rovaniemi, Finland. Tel: 358-50-562-6604. \\ E-mail: sanna.hyvarinen@rovaniemi.fi
}

Received: May 12, 2015

doi:10.5539/jedp.v5n2p14
Accepted: July 24, 2015

Online Published: September 28, 2015

URL: http://dx.doi.org/10.5539/jedp.v5n2p14

\begin{abstract}
The article illustrates findings from a larger study on the Finnish female leaders' paths to a leader's position. This sub-study analyzed the composition of a Finnish female leader as narrated by leaders themselves. It was studied through two specifying questions: what kinds of personal features female leaders considered important in their leadership practices and how do these women describe the emphases of leadership. This was a qualitative study in which 10 Finnish female leaders were interviewed in two phases in 2006 and 2011. According to the narratives, the important personal features were perseverance and rabidity, honesty and humbleness, as well as tolerance of criticism, adversities, and loneliness, which were analyzed in the light of the authentic leadership theory. The emphases of leadership included the dimensions of social interaction and being a bellwether. The study contributed a new narrative viewpoint to the definition of authentic leadership.
\end{abstract}

Keywords: leadership, female leaders, authentic leadership, narrative research

\section{Introduction}

The rapidly-changing worklife sets new challenges to leadership as well (Cascio, 2010; Syväjärvi \& Vakkala, 2012). Despite over a-hundred-year-long tradition of leadership research producing various theories and definitions (see e.g., Ladkin, 2010; Northouse, 2013; Solheim, 2000; Yukl, 2010), a holistic illustration of leadership is still lacking. Indeed, leadership as a phenomenon appears extremely versatile and complex (Ladkin, 2010).

What kind of leadership is expected in these days and what kinds of features should leaders possess? Regardless of numerous definitions, there are some central elements in leadership. On the one hand, leaders are expected to manage goals and objectives, vision, and substance. On the other hand, they also have to be people leaders, inspire employees to work toward goals and motivate, encourage, and support employee so that they engage and bear their responsibility over the success of the enterprise (Northouse, 2013; Syväjärvi \& Vakkala, 2012; Yukl, 2010).

In the 21 st century, the concept of authentic leadership has gained more and more attention (see e.g., Gardner et al., 2011; Gill \& Caza, 2015; Ladkin \& Spiller, 2013). It is based on positive psychological viewpoint to leadership (see e.g., Avolio \& Gardner, 2005; Seligman, 2011; Seligman, Steen, Park, \& Peterson, 2005). In this viewpoint, authenticity refers to the ownership and truthfulness of one's own experiences, including thoughts, emotions, needs, and beliefs (Harter, 2002; see also Ladkin \& Taylor, 2010).

Another important aspect of this study is female leadership. The modern time acknowledges women as capable leaders and their development into leadership position (see e.g., Frantsi, 2013; Lämsä, 2003; Lämsä et al., 2007). The purpose of this study is to analyze Finnish female leaders' narratives, their descriptions of themselves as leaders. How do they perceive themselves a leaders? What kind of characteristics do they perceive they need as leaders? Their narratives can help describing the composition of a Finnish female leader. Authentic leadership functions as the theoretical background that in this study will be used and understood as the narrative self (see Sparrowe, 2005). 


\subsection{Authentic Leadership}

Research on authentic leadership has recently included new definitions and theories (see e.g., Gardner et al., 2011; Gill \& Caza, 2015). It seems that the concept is still finding its form theoretically and empirically (Gardner et al., 2011). The definition has included, for example, the following four elements: self-awareness, relational transparency, balanced processing, and internalized moral perspective (see e.g., Avolio \& Gardner, 2005; Gardner et al., 2011; Gill \& Caza, 2015; Ladkin \& Taylor, 2010). Self-awareness refers to the ability to recognize one's strengths and weaknesses, one's personal way of make interpretations of facts, and one's personal influence on other people. Relational transparency refers to open distribution of information and open expression of one's own thoughts and emotions suitable to the situation. Relational transparency is seen to promote also other's confidence to express their opinions (see e.g., Avolio \& Gardner, 2005; Gardner et al., 2011; Gill \& Caza, 2015; Lewis, 2010; Northouse, 2013). Balanced processing means that information is analyzed objectively before decision-making by a leader. It refers to the ability to acknowledge and consult viewpoints that are different of the leader's own. Internalized moral perspective includes internalized and integrated self-regulation that makes it possible to act according to one's own moral values independent of outer pressure and situational factors. An authentic leader has a sense of right and wrong (Gardner et al., 2011; Gill \& Caza, 2015; Lewis, 2010; Northouse, 2013), creating a moral compass that the followers can follow as well (Cianci, Hannah, Roberts, \& Tsakumis, 2014). Authentic leaders genuinely aspire to understand their leadership in order to serve others efficiently (cf. Russell \& Stone, 2002). These four elements have offered a way to approach authentic leadership although there is some debate and questioning regarding them (see e.g., Hannah, Avolio, \& Walumbwa, 2014); however, the current viewpoint is that further research-based information is needed about the elements of authentic leadership (e.g., Gardner et al., 2011; Gill \& Caza, 2015).

In this study, the idea of authentic leadership is considered a useful theory—specifically when combined with the narrative approach. Sparrowe (2005) has viewed authentic leadership from a narrative perspective claiming that it is merely the emplotment - a concept originally created by Ricoeur (1992) - that unifies events into a coherent narrative of individual identity or character. According to Sparrowe (2005), the aforementioned four elements of authentic leadership can be analyzed from the narrative point of view. According to him, the path of self-awareness that leads toward authenticity is a narrative journey in autobiographical memory (cf., Hummel, 1991). Self-constancy means being both responsive and accountable in relationship to others. Transparency in leadership involves being explicit not only when narrating one's identity but also when explaining intentions to followers (Sparrowe, 2005). Boehm, Dwertmann, Bruch and Shamir's (2015) study explained that the stronger the leaders' organizational identity is, the more likely the external projection of the leader identity is to be, among others, authentic. Leaders make explicit alternative possible selves for followers, and followers incorporate those alternatives into their working self-concepts (Sparrowe, 2005; see also Shamir \& Eilam, 2005). When it comes to the ethical dimension of leadership, Sparrowe (2005) argues that authentic leadership should be equaled to ethics as such but ethical or moral leadership happens through the recognition of oneself in the regards of the other.

However, there are also criticism toward the elements of authentic leadership. For example, the question whether authentic leadership covers a moral component has been discussed (e.g., Shamir \& Eilam, 2005). On the other hand, moral perspective includes behaviors such as expressing honesty and integrity and displaying ethical decision making (Cianci et al., 2014). When leadership is considered a human strength, Seligman et al. (2005) include it within the virtue of justice. The definition is therefore close to the one presented by Sparrowe (2005) because it includes the obligation to others (see also Keefer, 1996).

A narrative approach to authentic leadership can provide new ways of learning and understanding leadership development (see e.g., Sparrowe, 2005) and leadership practices (see e.g., Dodge, Ospina, \& Foldy, 2006) at many dimensions. Danzig (1999) sees leadership narratives as a salient and irremovable part of the development: "Leadership is learning to analyse prior experiences in order better to understand how they shape future courses of action; it is learning to reflect on how actions are connected to cultural norms, to initial experiences growing up, to institutional histories and to professional experiences on the job" (p. 130). Similarly, Shamir and Eilam (2005) perceive that the construction of a life-story is a major element in the development of authentic leaders (see also Cooper, Scandura, \& Schriesheim, 2005).

\subsection{Viewpoints to Female Leadership}

Scientific research on female leaders started to emerge in the United States in the 1970s (Alvesson \& Billing, 2009). In Finland, female leadership research started in the 1980s (see e.g., Lämsä, 2003) and it has increased 
since the second half of the 1990s. According to Lämsä et al. (2007), research on Finnish female leaders have mostly focused on equality, discrimination, and career viewpoints. This study represents mainly the latter. In addition, studies have also been interested in work-family balance and women in the top brass (see e.g., Byron, 2005; Lämsä et al., 2007).

In early research, the concepts of "female leadership" and "female leaders" could refer to any managerial or leadership position (Vanhala, 2011). Some researchers classify and define leaders according to their position in the organization hierarchy, for example between top leadership/superior management, middle management, and lower management (see e.g., Huy, 2001; Rouleau \& Balogun, 2011; Vinkenburg, Jansen, Dries, \& Peppermans, 2014; Vanhala, 2011).

Roughly stated, female leadership studies seem to justify the significance of the theme from an equality or efficiency perspective or analyze women and men as fundamentally different or similar (Billing \& Alvessonin, 1989; see also Alvesson \& Billing, 2009; Lämsä, 2003). Those studies that are based on equality perceive men and women fundamentally similar (Billing \& Alvessonin, 1989; see also Alvesson \& Billing, 2009; Lämsä, 2003). Equality as a goal refers to expectations to have equal opportunities to both genders and therefore, it is ethically important. Meritocracy emphasizes similarity between genders as well. Women's expertise should be exploited to ensure the performance and efficiency of organizations. According to this view, women and men can move freely on the hierarchical ladders based on their expertise and qualifications, regardless of their gender (Billing \& Alvessonin, 1989; see also Alvesson \& Billing, 2009; Lämsä, 2003).

Studies based on difference bring out female leaders' special contribution to work; their experiences, thoughts, values, and methods differ from men's corresponding ones. These studies outline women's leadership styles as a sort of option to men's leadership styles, which can also be considered an ethically important viewpoint. Women bring feminine methods and thoughts, and as leaders, they can improve efficiency and success in their special manner (Billing \& Alvessonin, 1989; see also Alvesson \& Billing, 2009; Lämsä, 2003).

In summary, research on the significance or insignificance of gender or on gender-specific advantages or weaknesses in leadership are quite disputable and have different emphases depending on their ontological premises (see e.g., Alvesson \& Billing, 2009; Davidson \& Burke, 2004; Eagly \& Carli, 2003; Eagly \& Carli, 2007; Eagly \& Johannesen-Schmidt, 2001; Northouse, 2013; Oakley, 2000; Reskin, 2003; Rhode, 2003; Wirth, 2001).

This study analyzes the composition of leadership through ten Finnish female leaders' descriptions: how do they describe themselves as leaders. The purpose is not to analyze the differences between genders per se. However, it is relevant to introduce some perspectives of the theme. For instance, female leaders have been argued to emphasize more interaction than formal authority in their leadership style (Frantsi, 2013). Many studies mention women's abilities to act intuitively and empathically, to distribute information, interact openly, and delegate power, to support employees' self-esteem and initiative, and thus to motivate and increase interest in work in employees (Alvesson \& Billing, 2009, see also Frantsi, 2013). For example, a recent international study by Peus, Braun and Knipfer (2015) found out that factors such as achievement orientation, learning orientation, and role models emerged as crucial success factors for women's advancement to leadership positions. However, the researchers concluded that gender stereotypes still negatively influence evaluations of women and attitudes toward women in leadership positions, and therefore, further studies especially of the way women reach leadership positions and develop as leaders are needed (see also Murphy \& Johnson, 2011).

\section{Method}

\subsection{Research Questions}

This was a qualitative study employing a narrative approach. The purpose was to analyze how female leaders describe themselves as leaders and which tenets and advice they considered the most important.

The following questions were set for this research:

How do Finnish female leaders describe the composition of leadership?

It was studied through two specifying questions:

(1) What kinds of personal features they considered important in their leadership?

(2) How do the female leaders describe the emphases in their leadership activity?

\subsection{Narrative Method}


To answer the aforementioned questions, a narrative approach was chosen (see e.g., Lieblich, Tuval-Mashiach, \& Zilber, 1998; Polkinghorne, 1995; Riessman, 2008). Narrative research represents an approach that focuses on narratives as ways of transmitting and constructing information. The relationship between research and narrative can be viewed from two main perspectives: the research data can be narratives but research also produces a narrative about the world. Narrative research can refer to the information process as such, way of knowing, and the nature of information when it represents constructivism (Lieblich, Tuval-Mashiach, \& Zilber, 1998; Riessman, 2008). In this research, the narrative approach covered not only the methodological choices concerning data collection but also data analyses thus forming a framework for the study as a whole.

\subsection{Research Participants, Data Collection and Analysis}

This study focused on ten Finnish female leaders through a qualitative research design. The research participants were selected based on "Ammattiluokitus 2010 (AML 2010) [Classification of Occupations 2010]" classification which is based on the ISCO-08 (International Standard Classification of Occupations 2012). In this study, all participants are called "female leaders" without making distinctions with the level they operate (cf., Frantsi, 2013; Huy, 2001; Rouleau \& Balogun, 2011; Vinkenburg et al., 2014; Vanhala, 2011). Leadership positions were divided between four sectors: municipality, state, organization, and private sector. The operation level was defined with the so-called dartboard analogy: the closer the position is the bull's-eye, the higher level leader one is. When the dart board is combined with the four sectors, it was possible to locate suitable participants and reach as comprehensive target group as possible.

The data collection started by recruiting participants. A recruitment letter was sent to 12 female leaders representing municipality, state, and private sectors in 2006. In 2006, the organization sector was excluded from the research. The women were contacted by phone after sending the recruitment letters. Unexpectedly, the female leaders seemed very interested in the research. Of the first six leaders contacted by phone, everyone was willing to participate. Five of them were finally interviewed as the sixth interview was cancelled due to difficulties in finding suitable time for interview. The data collection was continued in 2011 by sending recruitment letters to five more female leaders: two of them were ones reached in the first phase but whose interviews were cancelled and three of them were new participants. Two of the group contacted in the first phase were interviewed because they represented such levels of leadership that would provide new perspectives to the data. Three other interviewees represented the organization sector which was considered important to include to the research in order to have comprehensive data.

Altogether, ten female leaders were interviewed: two of them represented municipality, two state, three organization, and three private sector. Therefore, they covered all sectors quite evenly. In addition, the study included women of different ages. The participants were born in 1945-1968.

A combination of narrative and theme interview was applied in this research which is a usable method of obtaining narratives from a certain point of view. The interview data were altogether 16.5 hours long. The interviews followed partly biographical structure as the interviewees were for example asked to talk about the nature of a leader's work. Narrative interview is biographical by nature but the emphases of the narrative can be directed in a certain direction (Lieblich, Tuval, \& Zilber, 1998; Polkinghorne, 1995; Riessman, 2008). In addition, biographical structure helps forming a comprehensive picture of the interviewee and perceive leadership as a part of life history that is constructed narratively in the interview situation. The combination of narrative and theme interview method was therefore useful: the interest was focused on particular themes in female leaders' biographies.

This study focused on female leaders' narratives about themselves as leaders. The analysis employed certain features of qualitative content and narrative analysis (Riessman, 2001). In practice this means that the data were analyzed with Polkinghorne's (1995) analysis of narratives and Lieblich, Tuval-Mashiach, and Zilber's (1998) approaches of holistic vs. categorical and content vs. form. The analysis of narratives focuses on the data as a whole: the narratives are classified into various categories based on types or themes similar to qualitative content analysis (e.g., Mayring, 2000). The analysis in this research started by dividing the data into three main sets: upbringing, education, and professional life. The third theme was analyzed from two different viewpoints: the female leaders' career development in Finland and the female leaders' descriptions of the composition of leadership. This article reports findings from the latter analysis.

After this preliminary analysis of narratives, the data were studied with approaches introduced by Lieblich, Tuval-Mashiach and Zilber (1998) that can further specify the way narrative data are read. The holistic approach focuses on the person and his or her life as a whole. Part of biographies are analyzed in the light of the unity. 
This study applied the holistic-content approach because the content of the whole narrative was taken into consideration although the actual analysis could focus on a certain theme. This viewpoint tries to find a general impression from the story and patterns that appear repeatedly after which it is possible to recognize holistic developmental processes and transitions in the narrative. Narratives were placed in a separate table that helped locating specific themes and patterns in the data. Color-codes were used for making the recognition of similar models and processes easier.

The results are introduced according to the research questions but highlighting the findings from the data. Therefore, the analysis was data bound. However in conclusions, we will discuss the findings in the light of some relevant models of leadership development, such as authentic leadership. Data excerpts are added to illustrate how female leaders described themselves as leaders. Excerpts also function as a support for the researcher's interpretations and narrative research approach (see e.g., Hatch \& Wisniewski, 1995). In order to secure the participants' anonymity, any specific information (e.g., the sector the leader represents) is not revealed. However, the leaders were given random codes that were uppercase letters.

\section{Results}

The results illustrate the composition of leadership as described by the Finnish female leaders. The two subchapters each answer one research question. First, the personal features considered important in leaders are introduced, followed by the emphases in leadership activity as narrated by the female leaders.

\subsection{The Most Important Personal Features in Leadership as Described in the Female Leaders' Narratives}

\subsubsection{Perseverance and Rabidity}

Some of the female leaders interviewed in this study emphasized their perseverance and stress-management skills. In their narratives, they described how they did not lose heart or become stressed because of setbacks or difficulties, but instead, they faced the challenges and described their ability to work persistently and perseveringly:

"I am pretty persistent. I work persistently to reach a goal. I do not let setbacks discourage me much." (Female leader D)

"I have an awfully good stress tolerance. If things are going badly and others start to lose their temper, my feet are even more firmly on the ground and I downright calm down the situation. Dammit, this is not so bad, we can do it. I think I am more persevering than others, but I always land on my feet whatever happened." (Female leader E)

Persistence as a personal feature is a manifestation of perseverance, but it can also include rabidity. Half of the women described how their persistent working was also prompt and even impulsive. However, it was described from two perspectives: rabidity as promptness was seen as a positive feature without which they might not have reached the leadership position. Rabidity as impulsiveness was, on the other hand, described as a feature needing some development as described the following female leaders:

"One thing that I educate myself every day is impulsiveness. - A good leader should not be unpredictable. A leader should be fundamentally even-tempered, and I am not like that. I do apologize easily when I notice that I have heated up a little. It is about one's nature. It just is. On the other hand, I am positive, too, to the same extent." (Female leader C)

"My bad feature is probably that I make new decisions so fast. I do it so fast that others find it difficult to adjust to them. - It is not always a good thing." (Female leader E)

\subsubsection{Honesty and Humbleness}

Important personal features also included honesty and humbleness. Some of the interviewees described how salient it is to be honest and humble with each and every work task, even if the situation was challenging. Honesty and humbleness as a leader's features and as a part of leader's action were seen admirable and worth pursuing:

"Openness and honesty are the goals of good leadership. Even in difficult matters, if you do it honestly and as well as you can, that will be the best asset. They are fundamental questions." (Female leader D)

Humbleness was described as a realistic attitude to work. Even if one had reached a top leadership position, one should not become proud and look down to others at the workplace. Work has to be done well without placing oneself on a pedestal. One of the female leaders described this element profoundly: 
"If you remember to keep up the attitude that you take the task in a somewhat humble manner and do not even think that you are saving the world here alone. Do not even think that you are the one deciding everything. - - If you put yourself at the top of the temple, you give yourself too much pressure. You just have to realize that you cannot do these things alone." (Female leader I)

\subsubsection{Tolerance of Criticism and Adversities}

The third narrative theme focused on the ability to tolerate criticism and adversities as a part of a leader's work (see also Hyvärinen, Uusiautti, \& Määttä, 2015). These features form a continuum to the features of humbleness and perseverance, willingness to accept one's incompleteness and ability to learn from and adjust to the challenging phases at work. No leader can avoid challenges, and criticism should not be taken personally but as a means to develop one's leadership skills:

"A leader has to be able to receive criticism and also analyze it. - Do not react too fast or hastily when there is a problem but truly analyze and ponder that 'okay, now this is the problem'.You have to listen to every side and gather a good picture about the problem." (Female leader B)

Already the analysis of the Finnish female leaders' career development showed how adversities were considered a part of a leader's work (Hyvärinen, Uusiautti, \& Määttä, 2015). The ability to tolerate setbacks and accept them was described as an important personal feature. In addition to setbacks, the female leaders mentioned risk-taking, problem-solving, and difficult decision-making as challenging areas of their work:

"You have to have the courage to take risks. —To seize even those situations that appear-unexpectedly. You cannot always play it safe." (Female leader D)

"Do not be afraid of making mistakes or failing, bankruptcy, losing your face, shame, guilt, because they belong to leadership. If you are a leader, you cannot succeed every time. -You will have successes but more failures." (Female leader J)

In some of the narratives, the tolerance of criticism and adversities also included the dimension of learning. Humbleness and honesty are needed to admit one's mistakes and to learn from them. Critical evaluation of one's action as a leader enables development and can lead to even better performances and well-being at work. This pattern was described for example as follows:

"I have learned the most from each mistake and failure and from the rebellious spirit in employees. Not from successes, which I luckily have had a few too, I mean having succeeded together. -Also the leader can develop and understand more widely and comprehensively the psycho-dynamics of a human being and the organization's way of thinking. " (Female leader J)

\subsubsection{Tolerance of Loneliness}

Some realities are especially included in leadership, and one of them, as described by the female leaders, was loneliness. Some of the female leaders surfaced in their narratives how a leader has to tolerate the position, act alone and be responsible for one's action as a leader:

"You have to tolerate that sort of loneliness. In other words, a leader's biggest mistake is to unite with followers or with some clique. - It is really important to maintain a certain distance. But the temptation to break it is really strong. You have to keep up with a balance. You have to somehow be aware of this risk. -You have to keep some things to yourself anyway." (Female leader B)

However, loneliness does not mean alienation. Some of the interviewees mentioned that leaders should not be friends with followers, while others found it possible with a certain reserve. This does not mean that the leaders could not care for their followers. However, when losing the balance, leading can become difficult or impossible, as described by one of the female leaders:

"Leadership requires certain laxity but not distance. There are too major risks, if I think philosophically. You can alienate and barricade yourself, especially when there are problems. - Which finally can lead to a situation where no information is flowing to the leader. -And the other risk is that you pal around too much and seek acceptance. - None of these are good, because both of them prevents you from being an actual leader." (Female leader B)

After analyzing the Finnish female leaders' narratives of their personal features as leaders, it was important to find out their emphases in leadership activity. 


\subsection{The Dimensions of Social Interaction and Being a Bellwether as the Emphases of Leadership}

\subsubsection{Female Leaders as Bellwethers}

Two dimension could be found from the Female leaders' descriptions of their emphases in leadership. On the one hand, they described their action as being a bellwether, leading the group, including shared vision and goal-orientation as well as the elements of trust and distribution of work. On the other hand, their narratives showed emphasis on social skills as a part of acting as a leader.

\section{Vision and goal-orientation}

Most of the female leaders emphasized the importance of vision in their work. Being a bellwether was described as the power of having a shared vision and creating willpower to work for the vision in their organizations:

"No company, association, or community cannot function if it does not have a proper mission, vision, and strategy. - You have to have the reason why we are here and what we want to pursue within the determined time limit, and what the methods to do that are." (Female leader A)

"My strength is that I get people along. If I want, even a nerd or elephants will follow me." (Female leader C)

Being a bellwether meant not only development of methods and organization but also self-development. Half of the interviewees brought up how they cannot rest but work for their position every day, are active and willing to develop:

"Take care that you keep up with the organization, and preferably, ahead of it. Develop yourself all the time. -You should not churn with the feeling of happiness after reaching the best result in the history or something. So what? -You have to remember to take the next step." (Female leader C)

Indeed, goal-orientation was a natural part of being a leader and a bellwether. Some female leaders described themselves as demanding leaders. The importance of goal-orientation in their work was profoundly internalized. The following data exerpts illustrate this kind of attitude in the female leaders:

"Apparently I am quite demanding — quite performance-oriented so that I want those results. But I also give space to do them, and try to respect the expertise as much as I can." (Female leader I)

"I do not intervene in [the experts'] work at all. Despite the fact that I follow that they work and make results." (Female leader G)

In addition to being demanding, the female leaders emphasized encouragement and inspiration. Enhancing employees' motivation was described as an important part of a leader's work by half of the interviewees. Bellwethers motivate, spur, and inspire employees to work toward shared goals. As the following exerpts show, the female leaders perceived their role as enablers:

"I see the leader's work as a backing role. The leader makes others' work possible. I have pursued it and I think I have succeeded to some extent too. This house has been successful lately." (Female leader G)

"Motivation. - To get the people along by you being in the middle. Sometimes, you have to be in the front. -Sometimes, you kick from behind. But anyway, you have to be in the middle of the troops acting as a mentor, spur, motivator, who make everyone flourish with their expertise. "(Female leader J)

\section{Trust and ability to distribute work}

Being a bellwether also included the elements of showing trust in employees. Most of the female leaders emphasized trust in their work. In addition, they acknowledged that trust in leader-follower relationships also meant that employees trusted the leader. Leaders are responsible to supervise work:

"You have to trust that the expert organization under your supervision works and you delegate the power. I am in charge of supervising that the power delegated downward is used properly. - The other side is, of course, this unpleasant word, the role of a controller. Due to my position, I have to, every now and then, check whether people have done what we have mutually agreed." (Female leader I)

The leaders' interviews showed the importance of work distribution and delegating of power not only in their organizations but also when it came to their partners or other networks. The leaders perceived that creating and having good networks was a crucial for their action and success as a leader. Likewise, the women highlighted the meaning of working together and showing respect and appreciation to experts' work and knowledge:

"Basically, I am not really good at anything. - I have always had employees who are better in every project I have been in. I have just been able to lead them to do these things together." (Female leader E) 
"Creating a network is important. - Not that, that who you know, but who know you in a positive way. Because then your life and things become much easier, and such doors can open to you that you could not have even dreamed about." (Female leader C)

\subsubsection{Social Skills}

Social skills in the female leaders' narratives included listening and caring action, responsibility and fairness as well as ability to create a positive atmosphere and provide positive feedback.

\section{Listening and caring action}

Most of the female leaders mentioned listening and discussion as important parts of a leader's work. They necessitate genuine presence as the following female leader explained:

"Many people do not understand that a leader's work is pretty much about listening to people. I dare to argue that a fourth or even a third of your time can be just listening to people. Genuine presence is important." (Female leader C).

The request of genuine presence illustrates caring action that the female leaders reported as the emphasis of their leadership. Showing empathy and hearing employees' problems manifest social skills that can be described as everyday caring about employees and social relationships at the workplace. However, the female leaders reminded that the balance was important in caring action too:

"Today's employees expect the leader have a face and voice. - Today's leaders taking to the streets illustrates some kind of sharing the human life. Even if you work with hard things, you can show with little acts that you care. Be interested, be present. - That is kind of low-profile, everyday caring." (Female leader J)

"But what was my mistake during the first years was that I listened to the personnel too much. - - There is a limit in being empathetic too." (Female leader I)

\section{Responsibility and fairness}

Not only does the leader bear responsibility for the operation, employees' work, and their own leadership especially in times of difficult decision-making and setbacks, but also by showing example. In the interviews, some of the female leaders described the nature of responsibility profoundly also by realizing how they may not even know all that happen or exist and, still, they are responsible for it as leaders.

"You understand that you are responsible for the operation of the organization even when you do not know what happens. It is just a sign of a lack of information flow and that you are a bad leader. But you still are responsible for that. The true responsibility means that you bear responsibility for your decisions, behavior, being example to the organization but also for unpleasant issues. It demands boldness, courage to seize issues, and not to turn your back." (Female leader B)

In leadership, social skills include the demand for justice and fairness. Employees have to be treated fairly, and therefore a leader has to be aware of her actions and how they can be interpreted as a manifestation of justice and equality.

"There are certain features that a leader has to possess. They are justice and equality. You treat everyone similarly." (Female leader A)

"Every employee has to be treated equally. - However, it does not mean that everyone has the same rights and this is the problem. - It just is that different tasks have different amounts of flexibility. You just have to explain that." (Female leader B)

\section{Ability to create a positive atmosphere and provide positive feedback}

Majority of the women emphasized the significance of a positive atmosphere and positive feedback. They described good team spirit, work satisfaction, and joy of work that originated in the creation of positive atmosphere. The female leaders stated that they worked as the examples of how to work diligently and create positivity. This was considered important for producing results:

"I have always thought that if you are interested, if you have a passion to do it; you can spread it to others. I have always been very passionate. I have been interested. And talked others into it." (Female leader E)

Giving and getting feedback is necessary in any work, and some of the female leaders also emphasized especially the importance of positive feedback. While two of them described it as a natural part of their leading, two others had found it difficult to provide positive feedback. Providing it necessitates leaders activity and 
ability to notice good performances and acknowledge them in context and timely manner. The leaders themselves described the complexity of positive spurring for example as follows:

"Logical thinking is probably my best side. Actually, I thought that giving positive feedback would be natural to me appeared to be more difficult that you could imagine. I easily forget it. I think positively about people but I do not always remember to say it." (Female leader B)

"I like it that I sense little things because I believe that the devil is on the details. -If you notice what people actually do and highlight them, it is great. -You say it aloud, it is that simple. People do not need much salary or fancy benefits, but that someone would notice and appreciate what they do; it is just small things." (Female leader C)

\section{Discussion}

The results showed the core elements of leadership as described by the Finnish female leaders. Their personal features could be combined into four narratives that were the narratives of perseverance and rabidity, honesty and humbleness, tolerance of criticism and adversities, and tolerance of loneliness. Self-awareness as an element of authenticity was well manifested in the female leaders' narratives when they contemplated themselves as leaders - their strengths and weaknesses. They had recognized them in their narratives of perseverance and rabidity, because this viewpoint provided a long-term analysis of their actions and features as leaders, and their consequences. Sparrowe (2005) referred here to the narrative journey in autobiographical memory. Indeed, when the female leaders looked back in their action, for example when assessing their rabidity, they realized when their action had taken them forward and when it had led to a setback.

Likewise, the elements of authentic leadership were evident in the female leaders' narratives of honesty and humbleness. They especially referred to increased self-awareness but also open information sharing, working diligently, and noticing of and reflecting on their action in regard to others (cf., Sparrowe, 2005) which connect their narratives of honesty and humbleness with the transparency and ethical dimensions of authentic leadership. Descriptions of honesty and humbleness showed internalized moral perspective (Avolio \& Gardner, 2005) to be important in their leadership.

The narratives of tolerance of criticism and adversities evince transparency, self-awareness, and self-constancy. The female leaders showed aspiration to self-development and increased self-understanding. Some of their narratives pointed out learning from mistakes, which implies that accepting one's incompleteness is crucial in leadership. Authentic leaders need the ability and willingness to constant learning and development (see also Niles, Amundson, \& Neault, 2011). Indeed, most of the current leadership theories define that leadership can be learned, tailored, and developed through authenticity (Syväjärvi \& Vakkala, 2012; Uusiautti et al., 2012). It includes that criticism and setbacks should be viewed as chances to develop and further one's self-awareness based on experiences and events along one's career and life in general-Peus et al. (2015) call this "learning orientation" in leadership development.

According to the Finnish female leaders' narratives, learning from mistakes and staying persistent in challenges and setbacks were essential for their success as leaders. This behavior can be explained also with the concept of resilience which means the ability to not only adjust to the adversity or crisis but also to act constructively and develop after it (Luthar, Cicchetti, \& Becker, 2000; Tugade \& Fredrickson, 2004). This kind of bouncing back refers to the ability to tolerate adversities and to work persistently in order to reach success (Luthans, 2002; Luthans et al., 2007). Thus, resilience is not just a feature but a dynamic process that enables positive adaptation (Rutter, 2008; see also Luthans, 2002). According to Sparrowe (2005), resilience as an important part of authentic leadership can be effectively represented by narratives. This was manifested in the female leaders' narratives as well.

The narrative of loneliness can also be interpreted through authenticity. On the one hand, it illustrates the requirement of transparency and self-constancy in leadership (Sparrowe, 2005). Leadership necessitates being aware of the nature of one's position and accepting the fact that eventually, the leader is responsible for all operation and decision-making.

The aforementioned narratives described the Finnish female leaders' features as leaders. In addition, they were asked to describe the emphases they considered crucial in leadership. The emphases could be roughly divided into two dimensions of goal-orientation and being a bellwether, and social skills. The former covered the importance of working toward a shared vision and goals. Likewise, Ladkin and Taylor (2010) showed that meaning-making or relating enables organizational members to work together toward a common interpretation of 
reality. When analyzing the social dimension of their work, the female leaders talked about caring and empathy but also about justice and creating a positive atmosphere, for example, by providing positive feedback actively. The female leaders' narratives showed that authentic leadership was closely connected with work satisfaction and performance at work (see also Syväjärvi et al., 2014). Indeed, according to Ladkin and Taylor (2010), the positive gives value to the human experience, knowledge, intuition, and learning as it provides an interpretation of life and working life.

\section{Conclusion}

The findings of this study supported the fact that leadership is a very complex phenomenon (Ladkin, 2010). When analyzing the composition of leadership based on the Finnish female leaders, one, inevitably, analyzes also what is good, even ideal leadership. This study employed the idea of authentic leadership, especially from the narrative viewpoint. The viewpoint appeared functional because leadership in these women's interviews evinced a development path that they contrasted, reflected, and analyzed against their experiences, thoughts, and ideas of how to become and be a good leader. Lewis (2010) interprets that authentic leadership is a sort of root function and that a style of leadership, whether it was transformative, charismatic, visionary, directive, or participatory, is a function that emerges from authenticity. Furthermore, Fleming (2001) has viewed narrative leadership as a strategic tool that can help leaders to maximize their sensemaking and sensegiving role in organizations (see also Hummel, 1991).

Likewise, Dodge, Ospina and Foldy (2005) point out how the narrative turn in leadership research has opened up new pathways for research that interprets social events and understanding the intentions and meanings of social actors by focusing on the narratives that people tell about their work. When the Finnish female leaders described the composition of their leadership, they simultaneously produced advice about how to lead well; they surfaced which practices they had found functional and beneficial.

In addition to the narrative viewpoint to authentic leadership, this study also contributed to the research on female leadership. However, instead of a truth, this study provided a viewpoint of how these female leaders described themselves as a leader without taking a stand on the similarity or difference between genders (cf., Alvesson \& Billing, 2009; Davidson \& Burke, 2004; Eagly \& Carli, 2003; Eagly \& Carli, 2007; Eagly \& Johannesen-Schmidt, 2001; Northouse, 2013; Oakley, 2000; Reskin, 2003; Rhode, 2003; Wirth, 2001). Therefore, the study contributed to the earlier research on female leadership as described in the literature review. In this study, leaders were selected based on the definitions provided by AML 2010. In some cases, it did not provide a very detailed description of the operations level. However, this did not have any significant influence in this research but this feature is worth recognizing on a large scale. All participants were called leaders in this study, which directly refers to the leadership position mentioned in AML 2010.

The interviewees' descriptions of leadership covered themselves as leaders, persons, and revealed also how they perceived a leader should be in general. The narratives included illustrations of the core composition of leadership on the one hand, but showed the women's own emphases as leaders on the other hand. When analyzing the interviews, this was seen a challenge: how to find the reality, how to know how these women truly acted as leaders?

The theory of authentic leadership provided a tool to address the women's narratives of themselves as leaders. However, it was noticed that the theory is still young, and opinions on its core elements are still finding their place. According to this study, while a narrative approach appeared to produce a suitable way of analyzing leadership development, further studies are needed to analyze the core elements of authentic leadership. For example, the connection between ideal leadership and authentic leadership still remained vague, yet interesting.

\section{References}

Alvesson, M., \& Billing, Y. D. (2009). Understanding gender and organizations (2nd ed.). London: Sage. http://dx.doi.org/10.4135/9781446280133

Avolio, B. J., \& Gardner, W. L. (2005). Authentic leadership development: Getting to the root of positive forms of leadership. The Leadership Quarterly, 16, 315-338. http://dx.doi.org/10.1016/j.leaqua.2005.03.001

Billing, Y. D., \& Alvesson, M. (1989). Four ways of looking at women and leadership. Scandinavian Journal of Management, 5(1), 63-80. http://dx.doi.org/10.1016/0956-5221(89)90006-7

Boehm, S. A., Dwertmann, D. J. G., Bruch, H., \& Shamir, B. (2015). The missing link? Investigating organizational identity strength and transformational leadership climate as mechanisms that connect CEO 
charisma with firm performance. The Leadership Quarterly, 26, 156-171. http://dx.doi.org/10.1016/j.leaqua.2014.07.012

Byron, K. (2005). A meta-analytic review of work-family conflict and its antecedents. Journal of Vocational Behavior, 67, 169-198. http://dx.doi.org/10.1016/j.jvb.2004.08.009

Cascio, W. F. (2010). The changing world of work. In P. A. Linley, S. Harrington, \& N. Garcea (Eds.), Oxford handbook of positive psychology and work (pp. 13-23). Oxford: Oxford University Press.

Cianci, A. M., Hannah, S. T., Roberts, R. B., \& Tsakumis, G. T. (2014). The effects of authentic leadership on followers' ethical decision-making in the face of temptation: An experimental study. The Leadership Quarterly, 25, 581-594. http://dx.doi.org/10.1016/j.leaqua.2013.12.001

Cooper, C. D., Scandura, T. A., \& Schriesheim, C. A. (2005). Looking forward but learning from our past: Potential challenges to developing authentic leadership theory and authentic leaders. The Leadership Quarterly, 16(3), 475-493. http://dx.doi.org/10.1016/j.leaqua.2005.03.008

Danzig, A. (1999). How might leadership be taught? The use of story and narrative to teach leadership. International Journal of Leadership in Education: Theory and Practice, 2(2), 117-131. http://dx.doi.org/10.1080/136031299293147

Davidson, M. J., \& Burke, R. J. (2004). Women in management worldwide: Facts, figures and analysis-An overview. In R. J. Burke, \& M. J. Davidson (Eds.), Women in management worldwide: Facts, figures and analysis (pp. 1-15). Aldershot: Ashgate Publishing.

Dodge, J., Ospina, S. M., \& Foldy, E. G. (2005). Integrating rigor and relevance in public administration scholarship: The contribution of narrative inquiry. Public Administration Review, 65(3), 286-300. http://dx.doi.org/10.1111/j.1540-6210.2005.00454.x

Eagly, A. H., \& Carli, L. L. (2003.) The female leadership advantage: An evaluation of the evidence. The Leadership Quarterly, 14, 807-834. http://dx.doi.org/10.1016/j.leaqua.2003.09.004

Eagly, A. H., \& Carli, L. L. (2007). Women and the labyrinth of leadership. Harvard Business Review, 85(9), 63-71.

Eagly, A. H., \& Johannesen-Schmidt, M. C. (2001). The leadership styles of women and men. Journal of Social Issues, 57(4), 781-797. http://dx.doi.org/10.1111/0022-4537.00241

Fleming, D. (2001). Narrative leadership: Using the power of stories. Strategy \& Leadership, 29(4). http://dx.doi.org/10.1108/s1.2001.26129dab.002

Frantsi, P. (2013). Johtajuutta etsimässä: Naislähijohtajan identiteettitarinan rakentuminen siivoustoimialalla [Looking for leadership: The construction of female immediate superiors' identities in cleaning industry]. Jyväskylä: Jyväskylä University Printing House.

Gardner, W. L., Cogliser, C. C., Davis, K. M., \& Dickens, M. P. (2011). Authentic leadership: A review of the literature and research agenda. The Leadership Quarterly, 22, 1120-1145. http://dx.doi.org/10.1016/j.leaqua.2011.09.007

Gill, C., \& Casa, A. (2015). An investigation of authentic leadership's individual and group influences on follower responses. Journal of Management. http://dx.doi.org/10.1177/0149206314566461

Hannah, S. T., Avolio, B. J., \& Walumbwa, F. O. (2014). Addendum to "Relationships between authentic leadership, moral courage, and ethical and pro-social behaviors". Business Ethics Quarterly, 24(2), 277-279. http://dx.doi.org/10.5840/beq201453011

Harter, S. (2002). Authenticity. In C. S. Snyder, \& S. J. Lopez (Eds.), Handbook of positive psychology (pp. 382-394). Oxford: Oxford University Press.

Hatch, J. A., \& Wisniewski, R. (1995). Life history and narrative: Questions, issues, and exemplary works. In J. A. Hatch, \& R. Wisniewski (Eds.), Life history and narrative (pp. 113-135). London: Falmer. http://dx.doi.org/10.1080/0951839950080102

Hummel, R. P. (1991). Stories managers tell: Why they are as valid as science. Public Administration Review, 5l(1), 31-41. http://dx.doi.org/10.2307/976634

Huy, Q. N. (2001). In praise of middle managers. Harvard Business Review, 79(8), 72-79, 160. 
Hyvärinen, S., Uusiautti, S., \& Määttä, K. (2015). From a novice to an expert. Finnish female leaders' eventful career developments. Journal of Studies in Education, 5(1), 1-26. http://dx.doi.org/10.5296/jse.v5i1.6756

International Standard Classification of Occupations. (2012). International Standard Classification of Occupations: ISCO-08. Volume 1, Structure, Group Definitions and Correspondence Tables. Geneva: ILO. Retrieved from http://www.ilo.org/wcmsp5/groups/public/---dgreports/ ---dcomm/---publ/documents/publication/wcms_172572.pdf

Keefer, M. W. (1996). The inseparability of morality and well-being: The duty/virtue debate revisited. Journal of Moral Education, 25(3), 277-291. http://dx.doi.org/10.1080/0305724960250302

Ladkin, D. (2010). Rethinking leadership. A new look at old leadership questions. Northampton, MA: Edward Elgar. http://dx.doi.org/10.4337/9781849805346

Ladkin, D., \& Spiller, C. (Eds.). (2013). Authentic leadership: Clashes, convergences and coalescences. New horizons in leadership studies series. Northampton, MA: Edward Elgar. http://dx.doi.org/10.4337/9781781006382

Ladkin, D., \& Taylor, S. S. (2010). Enacting the "true self": Towards a theory of embodied authentic leadership. The Leadership Quarterly, 21, 64-74. http://dx.doi.org/10.1016/j.leaqua.2009.10.005

Lewis, S. (2010). Positive psychology at work: How positive leadership and appreciative inquiry create inspiring organizations. Malden, MA: Wiley-Blackwell.

Lieblich, A., Tuval-Mashiach, R., \& Zilber, T. (1998). Narrative research: Reading, analysis and interpretation. Thousand Oaks, CA: Sage.

Luthans, F. (2002). The need for and meaning of positive organizational behavior. Journal of Organizational Behavior, 23, 695-706. http://dx.doi.org/10.1002/job.165

Luthans, F., Avolio, B. J., Avey, J. B., \& Norman, S. M. (2007). Positive psychological capital: Measurement and relationship with performance and satisfaction. Personnel Psychology, 60, 541-572. http://dx.doi.org/10.1111/j.1744-6570.2007.00083.x

Luthar, S. S., Cicchetti, D., \& Becker, B. (2000). The construct of resilience: A critical evaluation and guidelines for future work. Child Development, 71(3), 543-562. http://dx.doi.org/10.1111/1467-8624.00164.

Lämsä, A.-M. (2003). Miten näkyy nainen johtamistutkimuksessa? [How do women appear in leadership research?] In A.-M. Lämsä (Ed.), Näköaloja naisjohtajuuteen [Perspectives on female leadership] (pp. 25-46). Jyväskylä: University of Jyväskylä.

Lämsä, A.-M., Vanhala, S., Kontoniemi, N., Hiillos, M., \& Hearn, J. (2007). Naisjohtajuuden tutkimus Suomessa historiallisesta näkökulmasta [Research on female leadership in Finland from a historical perspective]. Liiketaloudellinen Aikakauskirja, 3, 294-321.

Mayring, P. (2000). Qualitative content analysis. Forum: Qualitative Social Research, 1(2). Retrieved from http://www.qualitative-research.net/index.php/fqs/article/view/1089/2385

Murphy, S. E., \& Johnson, S. K. (2011). The benefits of a long-lens approach to leader development: Understanding the seeds of leadership. The Leadership Quarterly, 22(3), 459-470. http://dx.doi.org/10.1016/j.leaqua.2011.04.004

Niles, S. G., Amundson, N. E., \& Neault, R. A. (2011). Career flow. A hope-centered approach to career development. Boston, MA: Pearson Education.

Northouse, P. G. (2013). Leadership: Theory and practice. (6th ed.). Thousand Oaks, CA: Sage.

Oakley, J. G. (2000). Gender-based barriers to senior management positions: Understanding the scarcity of female CEOs. Journal of Business Ethics, 27(3), 321-334. http://dx.doi.org/10.1023/A:1006226129868

Peus, C., Braun, S., \& Knipfer, K. (2015). On becoming a leader in Asia and America: Empirical evidence from women managers. The Leadership Quarterly, 26, 55-67. http://dx.doi.org/10.1016/j.leaqua.2014.08.004

Polkinghorne, D. E. (1995). Narrative configuration in qualitative analysis. In J. A. Hatch, \& R. Wisniewski (Eds.), Life history and narrative (pp. 5-23). London: Falmer Press. http://dx.doi.org/10.1080/0951839950080103

Reskin, B. (2003). What's the difference? A Comment on Deborah Rhode's “The difference 'difference' makes". 
In D. L. Rhode (Ed.), The difference "difference" makes: Women and leadership (pp. 59-65). Stanford, CA: Stanford University Press.

Ricoeur, P. (1992). Oneself as another. Chicago, IL: University of Chicago Press.

Riessman, C. K. (2001). Analysis of personal narratives. In J. F. Gubrium, \& J. A. Holstein (Eds.), Handbook of interview research: Context \& method (pp. 695-710). Thousands Oaks, CA: Sage. http://dx.doi.org/10.4135/9781412973588.d40

Riessman, C. K. (2008). Narrative methods for the human sciences. Los Angeles, CA: Sage.

Rhode, D. L. (2003). The difference "difference" makes. In D. L. Rhode (Ed.), The difference "difference" makes: Women and leadership (pp. 5-50). Stanford, CA: Stanford University Press.

Rouleau, L., \& Balogun, J. (2011). Middle managers, strategic sensemaking, and discursive competence. Journal of Management Studies, 48(5), 953-983. http://dx.doi.org/10.1111/j.1467-6486.2010.00941.x

Russell, R. F., \& Stone, A. G. (2002). A review of servant leadership attributes: Developing a practical model. Leadership in Organization Development Journal, 23, 145-157. http://dx.doi.org/10.1108/01437730210424

Rutter, M. (2008). Developing concepts in developmental psychopathology. In J. J. Hudziak (Ed.), Developmental psychopathology and wellness: Genetic and environmental influences (3-22). Washington, DC: APA.

Seligman, M. E. P. (2011). Flourish. A visionary new understanding of happiness and well-being. New York, NY: FreePress.

Seligman, M. E. P., Steen, T. A., Park, N., \& Peterson, C. (2005). Positive psychology progress. Empirical $\begin{array}{lllll}\text { validation of interventions. American Psychologist, } & \text { 60(5), } & \text { 410-421. }\end{array}$ http://dx.doi.org/10.1037/0003-066X.60.5.410

Shamir, B., \& Eilam, G. (2005). What's your story? A life-stories approach to authentic leadership development. The Leadership Quarterly, 16, 395-417. http://dx.doi.org/10.1016/j.leaqua.2005.03.005

Solheim, B. O. (2000). On top of the world: Women's political leadership in Scandinavia and beyond. Westport, $\mathrm{CN}$ : Greenwood.

Sparrowe, R. T. (2005). Authentic leadership and the narrative self. The Leadership Quarterly, 16, 419-439. http://dx.doi.org/10.1016/j.leaqua.2005.03.004

Statistics Finland. (2011). Ammattiluokitus 2010 [Classification of occupations 2010]. Helsinki: Statistics Finland.

Syväjärvi, A., Uusiautti, S., Perttula, J., Stenvall, J., \& Määttä, K. (2014). The reification of caring leadership in knowledge organizations. Research Journal in Organizational Psychology \& Educational Studies, 3(2), 93-105.

Syväjärvi, A., \& Vakkala, H. (2012). Psykologinen johtamisorientaatio-positiivisuuden merkitys ihmisten johtamisessa [Psychological leadership orientation-the meaning of positivity in people management]. In J. Perttula, \& A. Syväjärvi (Eds.), Johtamisen psykologia-Ihmisten johtaminen muuttuvassa työelämässä [Psychology of leadership-People management in changing working life] (pp. 195-226). Jyväskylä: PS-kustannus.

Tugade, M. M., \& Fredrickson, B. L. (2004). Resilient individuals use positive emotions to bounce back from negative emotional experiences. Journal of Personality and Social Psychology, 86, 320-333. http://dx.doi.org/10.1037/0022-3514.86.2.320

Uusiautti, S., Syväjärvi, A., Stenvall, J., Perttula, J., \& Määttä, K. (2012). "It's more like a growth process than a bunch of answers" University leaders describe themselves as leaders. Procedia-Social and Behavioral Sciences, 69, 828-837. http://dx.doi.org/10.1016/j.sbspro.2012.12.005

Vanhala, S. (2011). Career orientations of women middle managers. In L. Husu, F. Hearn, A.-M. Lämsä, \& S. Vanhala (Eds.), Women, management and leadership-Naiset ja johtajuus (pp. 30-37). Helsinki: Edita.

Vinkenburg, C. J., Jansen, P. G. W., Dries, N., \& Pepermans, R. (2014). Arena. A critical conceptual framework of top management selection. Group \& Organization Management, 39(1), 33-68. http://dx.doi.org/10.1177/1059601113492846 
Wirth, L. (2001). Breaking through the glass ceiling: Women in management. Geneva: ILO.

Yukl, G. (2010). Leadership in organizations. Upper Saddle River, NJ: Prentice-Hall.

\section{Copyrights}

Copyright for this article is retained by the author(s), with first publication rights granted to the journal.

This is an open-access article distributed under the terms and conditions of the Creative Commons Attribution license (http://creativecommons.org/licenses/by/3.0/). 